Working Paper No. 75/03

\title{
Steam as a General Purpose Technology: A Growth Accounting Perspective
}

Nicholas Crafts

(C) Nicholas Crafts

Department of Economic History

London School of Economics 
Department of Economic History London School of Economics

Houghton Street

London, WC2A 2AE

Tel: $\quad$ +44(0)2079556399

Fax: $\quad$ +44 (0)20 79557730 


\section{Introduction}

In recent years there has been an upsurge of interest among growth economists in General Purpose Technologies (GPTs). A GPT can be defined as "a technology that initially has much scope for improvement and evntually comes to be widely used, to have many uses, and to have many Hicksian and technological complementarities" (Lipsey et al., 1998a, p. 43). Electricity, steam and information and communications technologies (ICT) are generally regarded as being among the most important examples.

An interesting aspect of the occasional arrival of new GPTs that dominate macroeconomic outcomes is that they imply that the growth process may be subject to episodes of sharp acceleration and deceleration. The initial impact of a GPT on overall productivity growth is typically minimal and the realization of its eventual potential may take several decades such that the largest growth effects are quite longdelayed, as with electricity in the early twentieth century (David, 1991). Subsequently, as the scope of the technology is finally exhausted, its impact on growth will fade away. If, at that point, a new GPT is yet to be discovered or only in its infancy, a growth slowdown might be observed. A good example of this is taken by the GPT literature to be the hiatus between steam and electricity in the later nineteenth century (Lipsey et al., 1998b), echoing the famous hypothesis first advanced by Phelps-Brown and Handfield-Jones, 1952) to explain the climacteric in British economic growth.

Although there exists pioneering cliometric research on the social savings of both steam engines (von Tunzelmann, 1978) and railways (Hawke, 1970), there has never been an attempt to examine the long-run impact of steam technology on British economic growth during the late eighteenth and nineteenth centuries. This paper uses

Funding from ESRC Grant R000239536 is gratefully acknowledged. I am grateful for helpful suggestions from Bob Allen, Tam Bayoumi, Steve Broadberry, Richard Hills, Knick Harley, Bill Kennedy, Tim Leunig and Joachim Voth and for comments by seminar participants at Aberdeen, Cambridge, Glasgow, New University of Lisbon, Porto, Southampton, Stanford and York universities, at the February 2002 Canadian Institute for Advanced Research Economic Growth Program Meeting, 
growth-accounting to fill this gap and, in so doing, both to assess the validity of a GPT-based account of British economic growth and also to place the impact of steam in a comparative perspective.

In particular, three questions are addressed:

1. When did steam have its greatest impact on productivity growth ?

2. How does steam measure up to the contribution of ICT in the late twentieth century?

3. Was steam's contribution to productivity growth responsible for the chronology of trend growth in the economy overall ?

The answers will provide a way of contextualizing the modest growth now perceived to have characterized the first industrial revolution; recent estimates are summarized in Table 1. Whereas earlier estimates had seen TFP growth surging from 0.2 per cent per year before 1800 to 1.3 per cent per year in $1800-1830$ before falling back to 0.8 per cent per year in the mid 19th century (Feinstein, 1981), it now appears that there was a modest acceleration rather than a surge in TFP growth in the early 19th century followed by a long period of steady but unspectacular productivity growth. The apparent TFP growth climacteric suggested by the endpoint calculations reported in Table 1 is deceptive - when subjected to time series analysis there is at most a slight weakening of trend growth (Crafts et al., 1989).

The paper proceeds as follows. The growth accounting methodology used in the paper is set out in section 2 which also contains a benchmark calculation of the impact of ICT on recent American productivity growth. Section 3 describes and quantifies the diffusion of steam power in Britain between 1760 and 1910. Section 4 builds on these data to provide growth accounting estimates of the contribution of steam to labour productivity growth, uses these to address the questions posed in this introduction and offers some reflections on the elusive issue of TFP spillovers. Section 5 concludes.

and at the November 2002 Workshop on Technological Change at the Federal Reserve Bank of San Francisco. I am responsible for all errors. 


\section{Growth Accounting and Innovation}

Traditional growth accounting captures the contribution of technological change to growth through total factor productivity (TFP) growth, i.e., the Solow residual. With the standard Cobb-Douglas production function and competitive assumptions

$\mathrm{Y}=\mathrm{AK}^{\alpha} \mathrm{L}^{1-\alpha}$

the Solow residual is computed as

$\Delta \mathrm{A} / \mathrm{A}=\Delta \mathrm{Y} / \mathrm{Y}-\mathrm{s}_{\mathrm{K}} \Delta \mathrm{K} / \mathrm{K}-\mathrm{s}_{\mathrm{L}} \Delta \mathrm{L} / \mathrm{L}$

where $\mathrm{s}_{\mathrm{K}}$ and $\mathrm{s}_{\mathrm{L}}$ are the factor income shares of capital and labour respectively.

A straightforward generalization of this has been used in the growth accounting literature on ICT. This allows for different types of capital and distinguishes separate components of TFP growth. In the variant proposed in the well-known paper by Oliner and Sichel (2000), capital is divided into three types of ICT capital (computer hardware, computer software and telecom equipment) and other capital each of which is weighted by its own factor income share. TFP growth is decomposed into a component based on the production of ICT capital and other TFP growth. In turn, the latter is based on production of the rest of GDP deriving both from unrelated advances in technology and from (unremunerated) TFP spillovers from ICT. These might result, for example, from re-organization effects similar to those accruing when factories were re-designed after electricity had replaced steam (David and Wright, 1999).

Thus the growth accounting equation is written as

$\Delta \mathrm{Y} / \mathrm{Y}=\mathrm{s}_{\mathrm{KO}} \Delta \mathrm{K}_{\mathrm{O}} / \mathrm{K}_{\mathrm{O}}+\mathrm{s}_{\mathrm{Ki}} \Delta \mathrm{K}_{\mathrm{i}} / \mathrm{K}_{\mathrm{i}}+\mathrm{s}_{\mathrm{L}} \Delta \mathrm{L} / \mathrm{L}+\gamma(\Delta \mathrm{A} / \mathrm{A})_{\mathrm{ICTM}}+\phi(\Delta \mathrm{A} / \mathrm{A})_{\mathrm{NICTM}}$

where the subscript ${ }_{\mathrm{O}}$ indicates other capital, the subscript ${ }_{\mathrm{Ki}}$ indicates ICT capital of type $i$, the subscript ${ }_{\text {ICTM }}$ and NICTM indicate manufacture of ICT equipment and the rest of the economy, respectively, and $\gamma$ and $\phi$ are the gross output shares of these 
sectors. Modifying (3) to accounting for labour productivity rather than output growth we have

$$
\begin{aligned}
\Delta(\mathrm{Y} / \mathrm{L}) /(\mathrm{Y} / \mathrm{L})= & \mathrm{s}_{\mathrm{KO}} \Delta\left(\mathrm{K}_{\mathrm{O}} / \mathrm{L}\right) /\left(\mathrm{K}_{\mathrm{O}} / \mathrm{L}\right)+\mathrm{s}_{\mathrm{Ki}} \Delta\left(\mathrm{K}_{\mathrm{i}} / \mathrm{L}\right) /\left(\mathrm{K}_{\mathrm{i}} / \mathrm{L}\right)+ \\
& \gamma(\Delta \mathrm{A} / \mathrm{A})_{\mathrm{ICTM}}+\phi(\Delta \mathrm{A} / \mathrm{A})_{\mathrm{NICTM}}
\end{aligned}
$$

Thus the innovation of ICT is allowed to have impacts on growth both through an embodied, capital-deepening effect and through disembodied TFP growth.

Table 2 displays the estimates made by Oliner and Sichel (2000), as revised by them in an update on their research, where I have combined the contributions of the three types of ICT into a consolidated aggregate. Oliner and Sichel do not report an estimate for TFP spillovers from ICT nor do they attempt to identify cyclical effects on the utilization of factors of production.

It should be noted that this approach seeks only to benchmark the ex post ICT component of productivity growth. It does not answer the (much harder) question 'how much faster was productivity growth as a result of ICT ?' This turns on the counterfactual rates of growth of other capital in the absence of ICT, estimation of which would require a complex modelling exercise taking account of both 'crowding out' and 'crowding in' effects.

\section{The Diffusion of Steam Power in Britain in the 18th and 19th Centuries}

Kanefsky (1979a) provides the most complete reckoning of the growth of steam power in the British economy. Although the data are incomplete, notably in the period between the expiration of James Watt's patent in 1800 and the first returns under the Factory Acts in 1838 and again after 1870 when these returns ceased, the picture established by Kanefsky, which is summarized in Table 3, is accepted as broadly accurate.

The striking feature of Table 3 is that accumulation of capital in the form of steam engines was rather slow. James Watt's improved steam engine was patented in 1769. Yet, it was only in 1830 that steam reached parity with water as a source of 
power in the economy at which point only 160,000 steam horsepower had been installed representing about 1.5 per cent of the total capital stock. For a very long time, water power remained cost effective in many activities. Even in 1870 almost half of all steam power was used in mining and in cotton textiles while important sectors in the economy including agriculture and services (apart from transport) were virtually untouched by steam.

Similarly, in the United States the steam engine took a long time to gain the ascendancy over water power and it was not until the 1860 s that it supplied more horsepower. Detailed calculations in Atack (1979) show rapid declines in American steam and waterpower costs during the 19th century. Although these occurred more rapidly in steam than in water technology, only in the 1850 s did steam become a cheaper source of power for manufacturers in most locations.

Steam technology took a long time to perfect. The original Watt engines were a low pressure design whereas it was later realized that much lower coal consumption could be achieved with high pressure. In turn, reliable high pressure steam engines required big improvements in the design and manufacture of boilers. Although these engines were pioneered by Woolf in the early nineteenth century in Cornwall, where coal prices were very high and they were used in tin mining, only after the invention of the Lancashire boiler in the early 1840s were they an economic proposition in textile mills (von Tunzelmann, 1978). Much greater effort was then put into developing higher pressure steam power, especially after 1850 when progress in the theory of heat finally explained the rationale (Hills, 1989).

The upshot of these improvements in steam engine design was that coal consumption (per hp per year) improved from about $30 \mathrm{lb}$. with the Newcomen engines prior to James Watt, to $12.5 \mathrm{lb}$. with the Watt engine, $5 \mathrm{lb}$. with the move to high pressure in the mid 19th century and $2 \mathrm{lb}$ with very high pressure in the early 20th century (Kanefsky, 1979a; Winterbottom, 1907). In the meantime, maximum steam pressure in textile mills had risen from 60 in 1850 to 200 p.s.i in 1900 (Hills, 1989). 
These improvements in steam technology were reflected in the declining costs of steam power reported in Table 4. These estimates are for a benchmark case, namely a textile mill in Lancashire, and would not necessarily apply in other sectors or locations. Nevertheless, they match very closely the estimated modal experience in the United States where the annual costs of a horsepower of steam fell by just over 80 per cent between the 1820s and the 1890s Atack (1979, p. 423).

The history of railways is much better known and needs only brief description. This form of transport was initially wholly dependent on steam engines and can be seen as a manifestation of a developing GPT at work. The first major scheme was the Liverpool and Manchester railway opened in 1830. By the early 1850s the core trunk routes of the network were in place and about 7000 miles of track were open. Eventually the network grew to about 20000 miles. Railways were a massive investment by the British economy which was undertaken rapidly such that by 1855 their capital stock was equal to 30 per cent of GDP. Total train miles grew from about 60 million per year in the early 1850 s to 200 million by the mid-1870s and a little over 400 million by 1910 (Mitchell, 1988, pp. 541-547). As with the stationary steam engine, railway technology evolved greatly from the early days. Developments in engine and track design, braking, and signalling facilitated denser use of the rail network, faster trains, greater loads etc. The technology was still improving rapidly in the United States in the early 20th century (Fishlow, 1966).

\section{The Contribution of Steam to Productivity Growth, 1760-1910}

This section develops growth accounting estimates of the contribution of steam technology to British productivity growth based on implementing a formula equivalent to equation (4). Estimates which identify contributions from capitaldeepening and own TFP growth are developed separately for stationary steam engines and railways but, as with the estimates for ICT in Table 2, no attempt is made explicitly to quantify TFP spillovers. 
Table 5 sets out the growth accounting estimates for stationary steam engines. The rate of growth of the capital stock is based on the rate of growth of horsepower. This is obviously not quite the equivalent of estimating the growth of computer power using hedonic prices to deflate ICT expenditure but it does capture the key characteristic as seen by contemporaries. Moreover, with the move in the mid-19th century to measuring this in terms of 'indicated' rather than nominal horsepower this did reflect the real capabilities of this investment (Kanefsky, 1979a, pp. 23-28).

The contribution of TFP growth in the provision of steam power to the economy is estimated using the concept of social savings popularized in the cliometric literature on railways following Fogel (1964). This is simply the difference in resource cost of supplying a given volume of output using old and new versions of the technology. For constant input prices, the price dual measure of TFP growth is just equal to the rate of output price decline, i.e., TFP growth can be interpreted as the rate of real cost reduction (Harberger, 1998). Social savings from reductions in the cost of steam power as a proportion of GDP can therefore be used to estimate the rate of TFP growth. Indeed, this seems to be the only practical way to proceed.

Thus, the estimates of TFP growth in Table 5 are based on the changes in the annual cost of steam horsepower reported in Table 4, converted into real terms using the GDP deflator. For example, the social saving in 1910 relative to 1870 is obtained as follows. The annual cost of a horsepower in 1870 in 1900 prices was $£ 8.0 / 101.5=$ $£ 7.9$ while in 1910 it was $£ 4.0 / 100.2=£ 4.0$. The real cost decrease implies a rate of TFP growth of 1.7 per cent per year. The resource saving to the economy is calculated as $(7.9-4.0)=3.9 \times 9.659 \mathrm{mn} \mathrm{hp}=£ 37.67 \mathrm{mn}=1.84$ per cent of GDP which implies a growth contribution of 0.05 per cent per year during 1870-1910.

The period 1800-1830 where Table 5 assumes TFP growth of zero deserves a closer look. Based on the annual costs in Table 4 adjusted for falls in the general price level, TFP growth would be estimated as -0.6 per cent per year based on the textile districts. However, there clearly was some technological progress during this period in the Cornish steam engine, where high pressure was adopted, whereas, for Manchester, von Tunzelmann concluded that "there was little decline in the money 
costs of steam power from the turn of the century until the late $1830 \mathrm{~s}^{\prime \prime}(1978, \mathrm{p} .73)$. It seems most unlikely that for the economy as a whole TFP growth in steam power equalled that of the period 1830-50 so the bounds within which TFP growth lies is -0.6 to 1.2 per cent per year. None of the major conclusions of this paper would change significantly if another value within this interval were chosen.

The picture that emerges from Table 5 is fairly predictable given the discussion of section 3 but may well be rather surprising to economists brought up on the dramatic accounts of the industrial revolution of the Rostowian era. The contribution to growth made by the stationary steam engine was very small prior to 1830 , was considerably bigger in the second half of the 19th century than during the industrial revolution but was always quite modest. The slow diffusion of steam power accounts for this result and this is in turn explained by its lack of cost effectiveness in the era of low pressure steam. At no time did steam engines represent anything other than a small proportion of the total capital stock. TFP growth was relatively rapid at the point where the Watt engine appeared and again when it became possible generally to switch to much higher pressure steam engines in the mid-19th century.

Table 6 reports growth accounting estimates for the contribution of railways to productivity growth. Here the well-known studies by Foreman-Peck (1991) and Hawke (1970), which quantified the social savings of railways, have been re-worked into the growth accounting format of this paper. As the latter study showed, the impact of railways in the mid 19th century was appreciable but did not transform the overall growth rate because the sector was still quite small relative to GDP. By 1870, when railways were much larger, investment had subsided and TFP growth had ebbed. In this case, the maximal contribution to economic growth arrived relatively quickly but even so was not immediate.

Table 7 combines the results from the previous two tables to give an estimate of the total contribution of steam to British labour productivity growth. This confirms that the impact of steam was very small during the industrial revolution and peaked in the third quarter of the 19th century. Comparison of these estimates with those in Table 2 indicates that steam had a much smaller impact on annual productivity growth 
than did ICT even before the mid-1990s - at no time does steam's contribution match the 0.68 per cent per year of ICT in 1974-90. Of course, it remains to be seen how long-lasting is the impact of ICT and it would be premature to argue that the total effect of ICT will be the larger. ${ }^{1}$ What is apparent is that there was no equivalent to Moore's Law in the age of steam.

None of these estimates quantifies the extent of TFP spillovers. With regard to steam it is important to distinguish between the pre- and post-1850 periods. The literature on the social savings of steam engines and railways addressed this issue directly and argued strongly that TFP spillovers were negligible for the former period. The main point with regard to railways is that they seem to have very little impact on location decisions in an economy that had already been able to assemble the agglomerations of Birmingham and Manchester based on canals (Hawke, 1970, pp. 381-400; Turnbull, 1987). As far as steam engines are concerned, the main impact might be expected through technological change in textile production but von Tunzelmann (1978) pointed out that all the major advances were originally developed for other forms of power.

In the second half of the nineteenth century TFP spillovers from steam may well have been much more important. Rosenberg and Trajtenberg (2001) have argued that the improvements embodied in the Corliss steam engine, notably more sophisticated valves which allowed a continuous uniform flow of power as well as much greater energy efficiency, facilitated increased agglomeration and the realization of both internal and external economies of scale in nineteenth century manufacturing. The first Corliss steam engine was installed in Britain in 1861. Also, more indirect stimuli to agglomeration benefits may have arisen from the reductions in international

\footnotetext{
${ }^{1}$ It should be noted that the ICT contribution is based on hedonic prices for ICT equipment. This exaggerates the difference between ICT and steam though the point should not be overstated. A crude estimate can be obtained by comparing the rates of price decrease for computers and software according to the national accounts of the USA and UK, a country which continued to use traditional methods to estimate price declines for these items. The data presented in Oulton (2001) show that price decreases in the United States for computers (software) were greater by $7.3(0.6)$ per cent per year for 1979-89 and 8.8 (3.4) per cent per year for 1989-94. This suggests that the use of hedonic prices in Table 1 raises the capital-deepening contribution by a little less than 0.1 percentage points per year and the own TFP contribution by a similar amount.
} 
transport costs and enhanced specialization along lines of comparative advantage associated with the steamship.

It seems very probable that if TFP spillovers could be added into the estimates summarized in Table 7 that they would reinforce the main result, namely, that the strongest impact of steam power on British productivity growth was felt in the second half of the 19th century rather than earlier. It is, however, much less clear what might be implied for a comparison with ICT since TFP spillovers for that technology also remain to be convincingly quantified although some microeconomic evidence suggests they may be substantial (Brynjolfsson and Hitt, 2000).

What are the wider implications for the GPT literature of the results obtained in this paper? The first and most obvious message is that the major impact of a GPT on productivity may be very long-delayed. While electricity delivered its major boost to American economic growth about 40 years after the first commercial generating stations came on stream (David, 1991), the lag following James Watt's steam engine was about 80 years. In a proximate sense, this long delay resulted from the time taken to understand the true potential of steam in an era when science and technology were relatively primitive. In turn, this implied that steam power accounted for a very small share of the capital stock; only in the third quarter of the 19th century did the combined share of stationary steam engines and railways match that of ICT in the United States in the 1980s. In this context, the well-known Solow paradox - that you could see computers everywhere but in the productivity statistics - appears less puzzling and in fact the impact of ICT on labour productivity growth has appeared quite fast. Perhaps the true paradox is that so much was expected of ICT.

The second point to note is that these results help to explain the modest rate of productivity growth during the British industrial revolution which has now been established by quantitative research. Table 1 reported that TFP growth in the British economy during 1780-1830 averaged only 0.3 per cent per year. This can now be seen to be associated with the relatively weak initial impact of steam as a GPT. This should not really be a big surprise given the modest social savings from steam power 
in von Tunzelmann (1978) but this connection has not previously been made explicitly.

The third important aspect of the results is that, while they help explain a delay in the acceleration of productivity growth as Britain industrialized, they suggest that the claim that an ending of the massive application of steam power led to a late 19th century climacteric is implausible. In fact, the revisionist notion of a late 19th century climacteric in TFP growth at the level of the aggregate economy does not survive serious econometric investigation (Crafts et al., 1989). And it is clear from Tables 5 and 6 that any reduction in TFP growth from steam was very small - around 0.1 percentage points.

If, a more traditional view of the climacteric is taken, namely, that it is to be interpreted in terms of the growth of industrial output per worker, then the suggestion that there was a post-1870 slowdown based on a weakening of the application of steam power can be rejected by reworking the data underlying Table 4 in terms of industry rather than GDP. ${ }^{2}$ This is easy since the stationary steam engine was used in industry rather than the rest of the economy. The capital deepening contribution to industrial labour productivity growth is found to rise steadily over time from 0.04 in $1800-30$ to 0.11 in $1830-70$ and 0.20 percentage points per year in $1870-1910$. The objection made by Musson (1963) that the hypothesis is invalid because steampowered mechanization was still proceeding rapidly is sustained.

\section{Conclusions}

In the introduction three specific questions were posed. The answers that have been obtained in the paper can be summarized as follows.

First, steam had its greatest impact on productivity growth in the second half of the 19th century not during the industrial revolution.

\footnotetext{
${ }^{2}$ Industrial output per worker growth was 1.5 per cent per year in 1831-71 but fell to 0.8 per cent per year in 1871-1911 (Crafts and Mills, 2002).
} 
Second, in terms of its impact on the annual rate of productivity growth through capital-deepening and own TFP growth steam always had a much smaller impact than ICT even before the mid-1990s.

Third, slow productivity growth during the industrial revolution followed by acceleration in the mid-19th century is at least partly explained by steam's contribution; on the other hand, the idea of a late 19th century climacteric resulting from a weakening in the application of steam power is not persuasive.

In sum, seeking to base an account of 19th-century British economic growth primarily on the implications of steam is surely misconceived. At no time is its impact large enough to dominate. Perhaps in this respect there is a real difference from the world of ICT - but only time will tell. 


\section{References}

Atack, J. (1979), "Fact in fiction ? The relative costs of steam and water power: a simulation approach", Explorations in Economic History, vol. 16, pp. 409-37.

Brynjolfsson, E. and Hitt, L. (2000), "Beyond computation: information technology, organizational transformation, and business performance", Journal of Economic Perspectives, 14(4), 23-48.

Crafts, N. F. R. (1985), British Economic Growth during the Industrial Revolution. Oxford: Clarendon Press.

Crafts, N. F. R. (1995), "Exogenous or endogenous growth ? the industrial revolution reconsidered", Journal of Economic History, vol. 55, pp. $745-72$.

Crafts, N. F. R., Leybourne, S. J. and Mills, T. C. (1989), "The climacteric in late Victorian Britain and France: a reappraisal of the evidence", Journal of Applied Econometrics, vol. 4, pp. 103-17.

Crafts, N. F. R. and Mills, T. C. (2002), "After the industrial revolution: the climacteric revisited", mimeo, London School of Economics.

David, P. A. (1991), "Computer and Dynamo: the Modern Productivity Paradox in a Not-Too-Distant Mirror". In OECD, Technology and Productivity: the Challenge for Economic Policy. Paris: OECD, p. 315-348.

David, P. A. and Wright, G. (1999),"Early twentieth century productivity growth dynamics: an inquiry into the economic history of 'our ignorance"', University of Oxford Discussion Papers in Economic History, No. 33.

Feinstein, C. H. (1981), "Capital Accumulation and the Industrial Revolution". In (R. Floud and D. McCloskey, eds.), The Economic History of Britain since 1700, vol. 1. Cambridge: Cambridge University Press, pp. 128-42. 
Feinstein, C. H. (1988), "National Statistics, 1760-1920". In (C. H. Feinstein and S. Pollard, eds.), Studies in Capital Formation in the United Kingdom, 1750-1920. Oxford: Clarendon Press, pp. 257-471.

Fishlow, A. (1966), "Productivity and Technological Change in the Railroad Sector, 1840-1910". In (D. Brady, ed.), Output, Employment, and Productivity in the United States after 1800. New York: Columbia University Press, pp. 583-646.

Fogel, R. W. (1964), Railroads and American Economic Growth: Essays in Econometric History. Baltimore: Johns Hopkins University Press.

Foreman-Peck, J. (1991), "Railways and Late Victorian Economic Growth". In (J. Foreman-Peck, ed.), New Perspectives on the Victorian Economy. Cambridge: Cambridge University Press, pp. 73-95.

Harberger, A. C. (1998), "A vision of the growth process", American Economic Review, vol. 88, pp. 1-32.

Hawke, G. R. (1970), Railways and Economic Growth in England and Wales, 1840-1870. Oxford: Clarendon Press.

Hills, R. L. (1989), Power from Steam. Cambridge: Cambridge University Press.

Kanefsky, J. W. (1979a), "The Diffusion of Power Technology in British Industry", Unpublished Ph. D. thesis, University of Exeter.

Kanefsky, J. W. (1979b), "Motive power in British industry and the accuracy of the 1870 factory return", Economic History Review, vol. 32, pp. 360-75.

Lipsey, R. G., Bekar, C. and Carlaw, K. (1998a), "What Requires Explanation ?". In (E. Helpman, ed.), General Purpose Technologies and Economic Growth. Cambridge, Mass.: MIT Press, pp. 15-54.

Lipsey, R. G., Bekar, C. and Carlaw, K. (1998b), "The Consequences of Changes in GPTs". In (E. Helpman, ed.), General Purpose Technologies and Economic Growth. Cambridge, Mass.: MIT Press, pp. 193-218. 
Mitchell, B. R. (1988), British Historical Statistics. Cambridge: Cambridge University Press.

Musson, A. E. (1963), "British industrial growth during the 'Great Depression' (1873-96): some comments", Economic History Review, vol. 15, pp. 529-33.

Musson, A. E. (1976), "Industrial motive power in the United Kingdom, 1800-1870", Economic History Review, vol. 29, pp. 415-39.

Oliner, S. D. and Sichel, D. E. (2000), "The resurgence of growth in the late 1990s: is information technology the story ?", Journal of Economic Perspectives, vol. 14(4), pp. 3-22.

Oliner, S. D. and Sichel, D. E. (2002), "Information technology and productivity: where are we now and where are we going ?", mimeo, Federal Reserve Board.

Oulton, N. (2001), "ICT and productivity growth in the United Kingdom", Bank of England Working Paper No. 140.

Phelps-Brown, E. H. and Handfield-Jones, S. J. (1952), "The climacteric of the 1890s: a study in the expanding economy", Oxford Economic Papers, vol. 4, pp. 266-307.

Rosenberg, N. and Trajtenberg, M. (2001), "A general purpose technology at work: the Corliss steam engine in the late 19th century", CEPR Discussion Paper No. 3008.

Turnbull, G. L. (1987), "Canals, coal and regional growth during the industrial revolution", Economic History Review, vol. 40, pp. 537-60.

von Tunzelmann, G. N. (1978), Steam Power and British Industrialization to 1860. Oxford: Clarendon Press.

Winterbottom, J. (1907), Cotton Spinning Calculations and Yarn Costs. London: Longmans, Green \& Co. 
Table 1. Growth Accounts for Britain, 1760-1913. (\% per year)

$\begin{array}{lllll} & \text { Due to Capital } & \text { Due to Labour } & \text { TFP Growth } & \text { GDP Growth } \\ 1760-80 & 0.25 & 0.35 & 0.00 & \\ 1780-1831 & 0.60 & 0.80 & 0.30 & 0.6 \\ 1831-73 & 0.90 & 0.75 & 0.75 & 1.7 \\ 1873-99 & 0.80 & 0.55 & 0.75 & 2.4 \\ 1899-1913 & 0.80 & 0.55 & 0.05 & 1.4\end{array}$

Source: Crafts (1995). The estimates are based on a conventional neoclassical growth accounting equation where $\Delta \mathrm{Y} / \mathrm{Y}=0.4 \Delta \mathrm{K} / \mathrm{K}+0.6 \Delta \mathrm{L} / \mathrm{L}+\Delta \mathrm{A} / \mathrm{A}$. 
Table 2. Contributions to Labour Productivity Growth in US Non-Farm Business Sector, 1974-2001 (\% per year)

$1974-90 \quad 1991-5 \quad 1996-2001$

$\begin{array}{llll}\text { Capital Deepening } & 0.77 & 0.52 & 1.19 \\ \quad \text { ICT Capital } & 0.41 & 0.46 & 1.02 \\ \quad & 0.36 & 0.06 & 0.17 \\ \quad \text { Other } & 0.59 & 1.02 & 1.24 \\ \quad & 0.27 & 0.41 & 0.77 \\ \text { Total Factor Productivity } & 0.32 & 0.61 & 0.47 \\ \quad \text { ICT Sector } & & & \\ \quad \text { Other } & 1.36 & 1.54 & \\ \quad & & & 6.43 \\ \text { Labor Productivity Growth } & & 5.3 & 2.5 \\ \quad \begin{array}{l}\text { Memorandum Items } \\ \quad \text { ICT Capital Income Share (\%) }\end{array} & 3.3 & 1.9 & \end{array}$

Source: derived from growth accounting estimates of equation (4) by Oliner and Sichel (2002); labour quality is included in other TFP. 
Table 3. Sources of Power, 1760-1907 (Horsepower)

\begin{tabular}{lrrrrr} 
& 1760 & 1800 & 1830 & 1870 & \multicolumn{1}{c}{1907} \\
Steam & 5,000 & 35,000 & 160,000 & $2,060,000$ & $9,659,000$ \\
Water & 70,000 & 120,000 & 160,000 & 230,000 & 178,000 \\
Wind & 10,000 & 15,000 & 20,000 & 10,000 & 5,000 \\
Total & $\mathbf{8 5 , 0 0 0}$ & $\mathbf{1 7 0 , 0 0 0}$ & $\mathbf{3 5 0 , 0 0 0}$ & $\mathbf{2 , 3 0 0 , 0 0 0}$ & $\mathbf{9 , 8 4 2 , 0 0 0}$
\end{tabular}

Source: Kanefsky (1979a, p. 338); not including internal combustion engines. 
Table 4. Capital Cost and Annual Cost per Steam Horsepower per Year ( $f$ current)

$\begin{array}{lll} & \text { Capital Cost } & \text { Annual Cost } \\ 1760 & 42 & 33.5 \\ 1800 & 56 & 20.4 \\ 1830 & 60 & 20.4 \\ 1850 & 37 & 13.4 \\ 1870 & 25 & 8.0 \\ 1910 & 15 & 4.0\end{array}$

Note: the estimates are for a benchmark textile mill in a low coal cost region like Manchester annual costs include depreciation and interest costs, and running costs including coal and labour. In 1760 steam engines were not yet employed in this way and the estimate is for a typical Newcomen (preWatt engine) used in mining.

Sources: Capital cost: 1760, 1800 and 1830 from von Tunzelmann (1978, p. 49, 72, 75); 1850 and 1870 from Kanefsky (1979a, p. 158-9); 1910: Winterbottom (1907, p. 238). Running cost: 1760 from Kanefsky (1979a, p. 172-3); 1800, 1830 and 1850 from von Tunzelmann (1978, p. 74, 150); 1870 from Kanefsky (1979a, p. 175); 1910 from Winterbottom (1907, p. 238). 
Table 5. Contributions to British Labour Productivity Growth from Stationary Steam Engines, 1760-1910 (\% per year)

$\begin{array}{lllll}1760-1800 \quad 1800-30 \quad 1830-50 \quad 1850-70 & 1870- \\ & 1910\end{array}$

$\begin{array}{llllll}\text { Rates of Growth } & & & & \\ \quad \text { Steam HP per worker } & 4.3 & 3.9 & 4.2 & 5.2 & 3.9 \\ \text { TFP in steam power } & 2.8 & 0.00 & 1.2 & 3.5 & 1.7 \\ & & & & & \\ \begin{array}{l}\text { Contributions } \\ \text { Capital Deepening }\end{array} & 0.004 & 0.02 & 0.02 & 0.06 & 0.09 \\ \quad \text { TFP } & 0.005 & 0.00 & 0.02 & 0.06 & 0.05 \\ & & & & & \\ \text { Total } & \mathbf{0 . 0 1} & \mathbf{0 . 0 2} & \mathbf{0 . 0 4} & \mathbf{0 . 1 2} & \mathbf{0 . 1 4} \\ & & & & & \\ \begin{array}{l}\text { Memoranda (\%GDP) } \\ \text { Steam Income Share }\end{array} & 0.1 & 0.4 & 0.5 & 1.2 & 2.2 \\ \quad \text { Social Saving } & 0.2 & 0.0 & 0.3 & 1.2 & 1.8\end{array}$

Source: derived using growth accounting methods equivalent to Table 2.

Capital stock growth based on Kanefsky (1979a, p. 338) for growth of horsepower. From 1850, the figures are for indicated horsepower. The estimate of horsepower in $1870(1,668,000)$ is based on corrections for horsepower actually in use reported in Kanefsky (1979b, p. 373) and the horsepower estimate for $1850(487,500)$ is derived from Musson $(1976$, p. 435) adjusted in accordance with Kanefsky's suggestions to account for omissions and divergence between indicated and noimnal horsepower.

TFP growth in steam power based on the annual costs of steam to the user reported in Table 4 adjusted for inflation using the implicit GDP deflators in Mitchell (1988, pp. 831-9) and for 17601800 in Crafts (1985, p. 41).

Steam engine income share derived using capital costs reported in Table 4 to derive share of total capital stock using the estimates in Feinstein (1988, pp. 437-8).

The social savings of steam engines, which are derived using the period reductions in annual costs per horsepower in Table 4 multiplied by the estimates for horsepower is use, are used to estimate the TFP growth contribution, as described in the text. 
Table 6. Contributions to British Labour Productivity Growth from Railways, $1830-1910$ (\% per year)

$1830-50 \quad 1850-70 \quad 1870-1910$

Rates of Growth

Railway Capital per worker

22.8

0.4

TFP in railways

Contributions

Capital deepening

0.14

0.12

0.01

TFP

0.02

0.14

0.06

Total

0.16

0.26

0.07

Memoranda (\%GDP)

Railway profits share

0.6

2.1

2.7

Railway output share

1.0

4.0

6.0

Source: derived using growth accounting methods equivalent to Table 2.

Capital stock growth from Feinstein (1988, p. 452).

TFP growth pre-1870 from Hawke (1970, p. 302) and post-1870 from Foreman-Peck (1991, p. 81).

Railway profits and output shares based, respectively on net and gross receipts derived from ForemanPeck (1991, p. 76), Hawke (1970, p. 406) and Mitchell (1988, pp. 545-6). 
Table 7. Total Contribution to British Labour Productivity Growth from Steam Technology, 1760-1910 (\% per year)

$\begin{array}{ll}1760-1800 & 0.01 \\ 1800-30 & 0.02 \\ 1830-50 & 0.20 \\ 1850-70 & 0.38 \\ 1870-1910 & 0.21\end{array}$

Source: the combined impact of capital deepening and own TFP growth of steam engines and railways derived by summing the contributions from Tables 5 and 6 . 